Journal of Management and Economic
Studies
2019, 1(2): 184-34 DOI: $10.26677 / T R 1010.2019 .70$
Journal Homepage: https://www.jomaes.org

\title{
Effect of Organizational Citizenship Behaviour on Performance of Employees of Kumasi Technical University: Moderating Role of Work Overload
}

\author{
Gabriel Dwomoh \\ Kumasi Technical University, Institute of Research, Innovation and Development, \\ Ghana.
}

\author{
Lovia Adoma Gyamfi \\ Kumasi Technical University, Faculty of Health Sciences, Ghana.
}

Austin W Luguterah

Kumasi Technical University, Department of Management Studies, Ghana.

\begin{abstract}
The stressors of the teaching and non-teaching staff of tertiary institutions of Ghana are perceived to emanate from resource inadequacy and enormous work overload. This study therefore sought to investigate the moderating role of work overload in the relationship between OCB and the performance of employees using Kumasi Technical University as the study area. The quantitative study involved the survey of 250 staff through the administration of structured questionnaire and the analysis of data using hierarchical regression modeling method. The study revealed positive relationship between OCBs like conscientiousness, sportsmanship, courtesy, organizational loyalty and employee performance in the higher educational institution. Courtesy produced the highest effect on the performance of employees. Nonetheless, altruism and civic virtue behaviours of workers of the higher educational institution had no significant effect on the performance of employees. The workers engagement in these behaviours, however, enormously increases the workload and adversely affects the performance of the workers. Work overload was generally a Quasi-Moderator in the relationship between altruism, conscientiousness, sportsmanship, organizational loyalty and employee performance in the higher educational institution. Sportsmanship was the only factor that adversely moderated the effect of work overload on the performance of the workers. Based on these findings, the study recommends promotion of OCB practices and proper management of work overload of workers.
\end{abstract}

Keywords: OCBs, performance, employees, work overload, moderating role 


\section{Introduction}

For all successful organizations, human behaviour is a fundamental element (Romle, Talib \& Shahuri, 2016). In the constant strive to achieve success, firms are persistently turning their attention to financial capital, human and physical resources to become more efficient and productive (Goldberg \& Fleming, 2010). The performance of employees is a crucial predictor of firm performance and hence the need for effective management of human resource.

Organizational citizenship behavior (OCB) was first introduced by Organ in 1988 to describe employee's discretionary behaviours that directly promote the effective functioning of an organization, independently of an employee's objective productivity. OCBs personify some behaviours which are not imposed or stated in the job description of an employee. The behavior is relatively a matter of individual choice, such that its negligence is not commonly penalized (Farahbod et al., 2012). The behaviour and attitude of employees in an organization can positively or negatively affect customers' perception on the quality of service (Yaffe \& Kark, 2011). Managers and administrators of institutions can develop OCB through fostering positive working environment that could eventually develop a feeling of commitment, satisfaction and employees' loyalty (Farahbod et al., 2012). Employees largely exhibit OCB and less turnover rate when their level of satisfaction is high (Awang, Ahmad \& Zin, 2010).

The workforce of educational higher institutions is a foundation for the determination of educational development and academic excellence (Saleem, Nisar \& Imran, 2017). The faculty within the university is recognized as the person for the accomplishment of the missions of Universities. Universities as enlightening organizations with significant and sensitive mission require lecturers with high voluntary and conscientious performance to achieve its objective in educating and training students (Bagheri et al., 2011). Organizational Citizenship Behaviours through the lens of higher education may provide full understanding of the employment relationship for faculty and professional staff, as well as provide insight for institutional leaders (Saleem, Nisar \& Imran, 2017).

The stress of teaching and non-teaching staff of tertiary institutions in Ghana is perceived to emanate from resource inadequacy, inadequate funding, difficulty in securing research funds, poor co-worker relationship and enormous work overload (Ahmdy et al., 2007; Mate, 2014). The enormous volume of work overload at the tertiary institutions among staff is perceived as contributory factor to growing job dissatisfaction, rapid turnover and high attrition rate. There is persistent strike actions among the staff of the various tertiary institutions in Ghana as the professionals of this sector perceive their financial and non-financial compensation as inadequate in terms of matching with work overload. The load of work of teaching staff of tertiary institutions in Ghana is evident in the lecturer/student ratio of 1:37 for the humanities and 1:42 for the sciences that is perceived far above the values of 1:15 for the sciences and 1:18 for humanities recommended by the National Accreditation Board and National Council for Tertiary Education (National Accreditation Board \& National Council for Tertiary Education, Basic Statistics, 2011). In addition to work overload that exists at the workplace, some of lecturers take up part time appointments in other universities and departments to earn extra income to meet their growing needs. These actions therefore impair the efficacy of service delivery. Evidently, the enormous work overload is a stringent tool on the neck of exhibition of OCB by the employees of higher tertiary institutions in Ghana. More so, staff that wish to engage in OCB could be adversely affected due to the work overload situation.

Evidently, it is not clear the possible impact of OCB on the performance of employees in the higher tertiary institutions in Ghana, where employees are perceived to be loaded with work. The gap that can be witnessed in OCB literature as propounded by Khazaei, Khalkhali \& 
Eslami, 2011; Rose, 2012; Hakim, Nimran, Haerani \& Alam, 2014; Chelagat, Chepkwony \& Kemboi, 2015; Noni Huak, Pivi \& Hassan, 2015; Romle, Talib \& Shahuri, 2016 that were cited mostly in their recommendations for future research was that researchers have largely concentrated on OCB effect on employee performance, ignoring the possible moderating role of work overload in higher educational institutions. It was therefore necessary for one to contribute to knowledge by filling the literature gap in relation to moderating role of work overload of OCB and employees performance.

\section{Literature review and hypotheses}

In a study of higher educational institutions, Romle, Talib and Shahuri (2016) emphasized the effect of the various dimensions on employee performance and so reported positive effect of five dimensions of OCB on employee performance. Surveying 748 bank employees drawn from 25 banks within Nairobi in Kenya, Chelagat, Chepkwony and Kemboi (2015) reported that, altruism, and courtesy had positive and significant effect on employee performance. The study further concluded that organizational citizenship behavior is important factor for enhancing employee performance. The study of Khazaei, Khalkhali and Eslami (2011) examined the relationship between OCB and the performance of teachers in West of Mazandaran Province in Iran and concluded that there is a significant relationship between $\mathrm{OCB}$, its components and high school teachers' performance. Hakim, Nimran, Haerani and Alam (2014) also reported positive relationship between $\mathrm{OCB}$ and the performance of lecturers of public university in Makassar, South Sulawesi, Indonesia. Noni Huak, Pivi and Hassan (2015) showed that OCB dimensions are positively related to employee commitment and performance. Basu, Pradhan and Tewari (2017) in their exploration of the relationship between OCB and employee performance through the survey of 501 workers in 15 healthcare organizations in Kolkata in India concluded that OCB significantly predicts job performance in healthcare organizations. Agustiningsih et al (2016) in the survey of 138 Account Representative (AR) Supervision of the work in the Tax Office in Malang area revealed no relationship between OCB and the performance of AR Supervisors. Tehran, Abtahi and Esmaeili (2013) in the study of OCB linkage with the performance of Staff of Qazvin University of Medical Sciences and Health Services reported that OCB dimensions like altruism, work ethics, sportsmanship and civic behaviour positively stimulates employee performance. However, polite and considerate dimensions of OCB had no relationship with employee performance.

OCB is partly determined by the role of workers in organization. In the health sector for instance, nurses relatively exhibit higher level of altruism, courtesy, conscientiousness and total organizational citizenship behavior compare to physicians (Kılınç \& Ulusoy, 2014). The study of Kılınç and Ulusoy (2014) surveying 317 health workers reported a positive significant relationship between conscientiousness, civic virtue and altruism dimensions of OCB and employee performance. However, the study reported no significant relationship between the courtesy dimension of OCB and employee performance. A Meta analytical study of the relationship between OCB and employee performance by Nielsen, Hrivnak and Shaw (2009) in later period also suggested positive effect of $O C B$ on employee performance. Based on the reviewed literature or studies, the study hypothesizes that:

$\mathrm{H}_{1}$ : OCB positively affects employee performance

Turing attention to work overload and employee performance, previous studies have provided evidence of statistical significant relationship between work overload and employee performance. The studies showed that work overload lead to poor performance of employees which ultimately leads to employee job dissatisfaction (Tahir et al 2012). Paktinat and Rafeei (2012) reported work overload as a key predictor of employee performance. The researchers 
further emphasized that work overload is harmful not to just the employees but to the entire organization (Obiora \& Iwuoha, 2013). Obiara and Iwuoha (2013) further emphasized that females are less satisfied from their jobs in relation to role work overload due to home responsibilities and job responsibilities as well. Role work overload negatively related to job performance (Bozkurt et al, 2012).

Tahir et al. (2012) in their exploration of the effect of work overload on task related performance and customer orientation of employees in WAPDA showed that a decline in performance happened as a result of work load which led to less customer orientation among the employees. Karatepe (2013) in the study of 110 full-time frontline hotel employees and their managers in Romania indicated that employees who have heavy workloads and are unable to establish a balance between work (family) and family (work) roles are emotionally exhausted. Such employees in turn are less embedded in their jobs and display poor performance in the service delivery process. Tahir, et al (2012) reported that a decline in performance occurred as a result of work load which led to less customer orientation among the employees. Ashfaq, Mahmood and Ahmad (2013) in a survey of 300 employees working in banks of Pakistan showed that employee performance is affected by work overload because in banking sector, as working hours are prolong, it becomes tough for the employees to manage time for their families and personal life. Abbasi (2015) in the survey of 123 employees from different public sector employees reported negative relationship between work overload and employee performance. Also, Ali and Farooqi (2014) reported adverse effect of work overload on employee performance. However Saranani (2015) in the study of 150 employees at the Department of Public Works Southeast Sulawesi Province revealed no significant relationship between work overload and employee performance. Work overload affects employee performance and the associates of the work overload also affects the outcome of employees (McGinnity \& Whelan, 2009). The absence of work and role sharing are behind role overload (Ashfaq, Mahmood \& Ahmad, 2013). Based on the reviewed literature, the study hypothesizes that:

$\mathbf{H}_{2}$ : Work overload negatively affects employee performance

Looking at the moderating role of work overload in the effect of OCB on employee performance, available literature indicates that not many researchers have looked into the moderating role of work overload in the relationship between OCB and employee performance. However, several studies have touched on the effect of work overload on employee performance. Some researchers have also provided evidence of moderating effect of work overload in the effect of OCB on employee performance. Employees who have a hard time keeping up with the pace of work imposed on them may consider OCB a distraction that keeps them from meeting work-related goals (Podsakoff et al., 2009; Boyd et al., 2011). If so, they may feel less compelled to leverage their skills to engage in activities for which they are not directly rewarded or that are not part of their formal job description. Thus, in the presence of strong work overload, engaging in OCB is more likely beyond employees' reach or capability. In the same vein, Kaplan et al (2009) reason that employees who experience stress due to high workload, tend to engage less in OCB than their counterparts who do not experience stress, because they lack the time and energy to contribute to "non-essential" discretionary acts such as OCB. Based on the review and the provided analogy, the study hypothesizes that:

$\mathrm{H}_{3}:$ Work Overload moderates the effect of OCB on Employee Performance

From the discussions emanating from the literature review together with the hypotheses formulated above, it is possible for us to develop a conceptual framework of OCB, work overload and employee performance as shown in the figure below: 


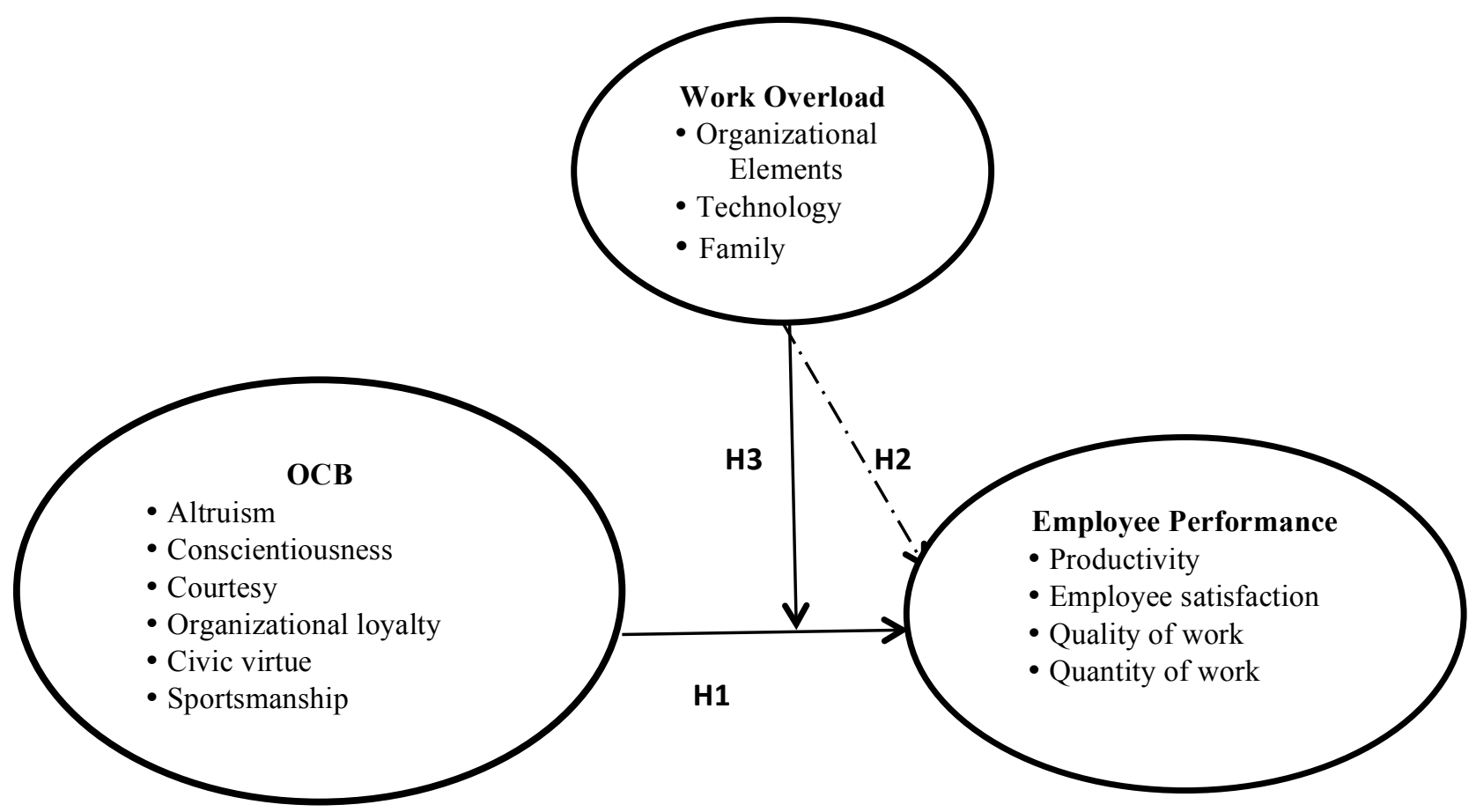

Figure 1: Conceptual framework of $\mathrm{OCB}$, work overload and employee performance

\section{Methodology of the Study}

The target population for the study is all the staff of Kumasi Technical University as at January, 2018. The total staff of the Technical University within this period is 659 made up of 282 teaching and 377 non-teaching staff. The distribution of the teaching staff of the university based on faculties is shown in Table 1.

Table 1: Distribution of Staff by Faculty

\begin{tabular}{|l|c|}
\hline \multicolumn{1}{|c|}{ Faculty } & Number of Staff \\
\hline Teaching Staff & \\
\hline Applied Sciences & 44 \\
\hline Built and natural environment & 31 \\
\hline Business and management studies & 92 \\
\hline Creative Art and Technology & 14 \\
\hline Engineering & 58 \\
\hline Entrepreneurship and Enterprise Development & 17 \\
\hline Health Sciences & 17 \\
\hline Graduate Studies, Research and Innovation & 9 \\
\hline Sub-Total & $\mathbf{2 8 2}$ \\
\hline Non-teaching/Administrative Staff & $\mathbf{3 7 7}$ \\
\hline Grand Total & $\mathbf{6 5 9}$ \\
\hline
\end{tabular}

Source: Planning Unit, KsTU (2018)

In order to determine the sample size for the study, the researchers adopted De vaus method of sample calculation. The De Vaus (2002) sample size calculation method requires a defined target population and assumes a significant level of 0.05 (5\%) or confidence level of $95 \%$. The De Vaus (2002) calculation method produced a sample size of 250 staff of Kumasi Technical University which is shown as follows: 
$n_{s s}=\frac{N_{R P}}{1+N_{R P}\left(\alpha_{E}\right)}=\frac{659}{1+659(0.05)^{2}}=\frac{659}{2.6475}=250 \mathrm{Staff}$

where

$\mathrm{n}_{\mathrm{ss}}=$ Sample Size

$\mathrm{N}_{\mathrm{RP}}=$ Research Population

$\alpha_{\mathrm{E}}=$ Error Margin

In determining the sample size for each of the sub-sets (faculties), the Krecjie and Morgan formula was used. The formula and its presentation in the calculation of the sub-sample size are shown in the Table below:

Table 2: Distribution of Sample Size by Faculty

\begin{tabular}{|l|c|c|c|}
\hline \multicolumn{1}{|c|}{ Faculty } & No. of Staff & $(\mathbf{X S}) / \mathbf{P}$ & Sample Size \\
\hline Teaching Staff & & & \\
\hline Applied Sciences & 44 & $44(250) / 659$ & 17 \\
\hline Built and natural environment & 31 & $31(250) / 659$ & 12 \\
\hline Business and management studies & 92 & $92(250) / 659$ & 35 \\
\hline Creative Art and Technology & 14 & $14(250) / 659$ & 5 \\
\hline Engineering & 58 & $58(250) / 659$ & 22 \\
\hline Entrepreneurship and Enterprise Dev't. & 17 & $17(250) / 659$ & 6 \\
\hline Health Sciences & 17 & $17(250) / 659$ & 6 \\
\hline Graduate Studies, Research and Innovation & 9 & $9(250) / 659$ & 3 \\
\hline Sub-Total & $\mathbf{2 8 2}$ & $\mathbf{2 8 2 ( 2 5 0 ) / 6 5 9}$ & $\mathbf{1 0 7}$ \\
\hline Non-teaching/Administrative Staff & $\mathbf{3 7 7}$ & $\mathbf{3 7 7 ( 2 5 0 ) / 6 5 9}$ & $\mathbf{1 4 3}$ \\
\hline Grand Total & $\mathbf{6 5 9}$ & $\mathbf{6 5 9 ( 2 5 0 ) / 6 5 9}$ & $\mathbf{2 5 0}$ \\
\hline
\end{tabular}

Source: Planning Unit, KsTU (2018)

$$
\begin{aligned}
& s=\frac{X S}{P} \\
& s=\text { Sub-sample size for each faculty } \\
& X=\text { Population of employees of each faculty the University } \\
& S=\text { Total sample size for the study } \\
& P=\text { Total population of all the faculties }
\end{aligned}
$$

The study engaged a multistage sampling procedure in the sampling of the staff of Kumasi Technical University. For the initial phase of the multistage sampling procedure, the staff of the University were stratified into teaching and non-teaching staff using the stratified sampling method. The staff within each stratum were further stratified on the basis of faculty or department. The teaching staff were stratified based on faculty whereas the non-teaching staff were stratified based on department. Simple random using the lottery method was employed in the selection of delegated sub-sample size within each stratum of the teaching and non-teaching staff. The lottery was carried out by representing staff within strata by strip of papers and selected the delegated sub-sample size without replacement.

The instrument used for collecting data was mainly questionnaires. This instrument was used to collect primary data needed for the study. The questioning formats employed in the designing of the questionnaire were choice of categories, binary responses (Yes or No) and Likert scaling method. Notwithstanding the many available modes of administering 
questionnaires, the face-to-face method was employed in the administration of the questionnaires to the staff of the University. The face-to-face method was employed to ensure higher response rate.

A single questionnaire was designed for the employees of the Kumasi Technical University. The questionnaire for the staff was designed in four parts. The part one of the questionnaire solicited information on the socio demographic characteristics of the staff of the University. The second part of the questionnaire also solicited information on the organizational citizenship behaviour of the staff. The key elements considered in this part of the questionnaire were altruism, Conscientiousness, civic virtue, sportsmanship, courtesy, and organizational loyalty. The third section of the questionnaire also solicited for data on work overload of staff whilst the fourth part was on staff performance.

The collected data was processed and fed into the SPSS IBM Version 20 for the appropriate statistical analyses. The data was analysed using both descriptive and inferential analytical methods. The descriptive method used for the study included frequency (percentage), measures of central tendency and measures of dispersion. The inferential analytical methods employed were multiple regression and correlational analysis. However, the validity of the study items was examined through factor analysis.

\section{Data Presentation and Analysis}

The main objective of the study is to assess the effect of organizational citizenship behaviour on performance of employees of Kumasi Technical University, the moderating role of work overload. In order to achieve the objective of the study, it was imperative that the socio demographic characteristics of the respondents used for the study were analyzed since age, occupation, gender, educational and marriage status have relationship with the way people think and analyze situations. This presumption can have direct influence on the way the questionnaires were completed by the respondents of the study. The analyses of the socio demographic characteristics of the respondents based on questionnaires retrieved from them showed that more respondents between the age of 31 to 40 years $(47.2 \%)$, more male $(56.8 \%)$, dominant respondents who are married $(56.4 \%)$ and more master degree holders $(38.4 \%)$ participated in the study.

\subsection{Organizational Citizenship Behaviour}

There are various dimensions of organizational citizenship behavior that can be practiced by organizations. The researchers through literature review selected the ones that are commonly practiced by organizations to be used for the study and these included altruism, conscientiousness, sportsmanship, civic virtues, courtesy and organizational loyalty. These dimensions were used to ascertain the extent to which they were practiced by the organization used for the study and the descriptive results can be presented in Table 3 below:

Table 3: ОСB Practices of the Institution

\begin{tabular}{|l|c|c|c|c|c|}
\hline & $\mathrm{N}$ & Min & Max & Mean & SD \\
\hline Altruism & $\mathbf{2 5 0}$ & $\mathbf{1}$ & $\mathbf{5}$ & $\mathbf{3 . 9 2}$ & $\mathbf{. 8 3}$ \\
\hline $\begin{array}{l}\text { I give my time to help employees with work-related } \\
\text { problems. }\end{array}$ & 250 & 1 & 5 & 3.86 & 1.03 \\
\hline I take time out of my day to help train new employees & 250 & 1 & 5 & 3.52 & .92 \\
\hline I help orient new people even though it is not required & 250 & 1 & 5 & 3.54 & .96 \\
\hline $\begin{array}{l}\text { I talk to other employees before taking actions that } \\
\text { might affect them }\end{array}$ & 250 & 1 & 5 & 3.73 & 1.20 \\
\hline
\end{tabular}




\begin{tabular}{|c|c|c|c|c|c|}
\hline $\begin{array}{l}\text { I am always ready to lend a helping hand to those } \\
\text { around me }\end{array}$ & 250 & 1 & 5 & 3.98 & 1.13 \\
\hline I support employees who have problems at work & 250 & 1 & 5 & 3.98 & .90 \\
\hline $\begin{array}{l}\text { I share my knowledge and expertise with other } \\
\text { employees }\end{array}$ & 250 & 1 & 5 & 4.05 & .98 \\
\hline Conscientiousness & 250 & 1 & 5 & 3.74 & .81 \\
\hline I rarely takes long lunches & 250 & 1 & 5 & 3.62 & 1.27 \\
\hline I don't take extra breaks & 250 & 1 & 5 & 3.62 & 1.16 \\
\hline I don't take unnecessary time off work & 250 & 1 & 5 & 3.84 & 1.14 \\
\hline My attendance at work is above the norm & 250 & 1 & 5 & 3.86 & 1.13 \\
\hline Civic Virtue & 250 & 1 & 5 & 4.06 & .71 \\
\hline I am punctual & 250 & 2 & 5 & 4.10 & .99 \\
\hline $\begin{array}{l}\text { I attend functions that are not required but help the } \\
\text { company's image }\end{array}$ & 250 & 1 & 5 & 3.55 & 1.05 \\
\hline I volunteer to take additional tasks, not part of work & 250 & 1 & 5 & 3.56 & 1.00 \\
\hline $\begin{array}{l}\text { I attend training sessions that am not required to } \\
\text { attend }\end{array}$ & 250 & 1 & 5 & 3.58 & 1.08 \\
\hline I attend and actively participate in company meetings & 250 & 1 & 5 & 3.87 & .88 \\
\hline I create healthy and cheerful atmosphere at workplace. & 250 & 1 & 5 & 4.21 & .90 \\
\hline Sportsmanship & 250 & 1 & 5 & 3.88 & .72 \\
\hline I attend and participate in meetings & 250 & 1 & 5 & 3.97 & .89 \\
\hline $\begin{array}{l}\text { I read and keep up with firm announcements, memos, } \\
\text { and so on }\end{array}$ & 250 & 1 & 5 & 3.91 & .86 \\
\hline $\begin{array}{l}\text { I make suggestions for improving the firm's policies } \\
\text { and practices }\end{array}$ & 250 & 1 & 5 & 3.70 & .93 \\
\hline I keep up with changes at my workplace & 250 & 1 & 5 & 3.86 & .80 \\
\hline I keep trivial complaints to myself & 250 & 1 & 5 & 3.60 & 1.05 \\
\hline I do not take personal credit for teamwork & 250 & 1 & 5 & 3.62 & 1.05 \\
\hline I try not to find fault with other employees & 250 & 1 & 5 & 3.58 & 1.10 \\
\hline I focus on the positive aspects of my work & 250 & 1 & 5 & 4.15 & .94 \\
\hline Courtesy & 250 & 1 & 5 & 4.04 & .69 \\
\hline I am mindful of how my behavior affects other staff & 250 & 1 & 5 & 4.05 & .99 \\
\hline I take steps to try to prevent problems with other staff & 250 & 1 & 5 & 4.16 & .71 \\
\hline I don't abuse the rights of other staff & 250 & 1 & 5 & 4.13 & .90 \\
\hline I do not speak ill of supervisor and co-workers & 250 & 1 & 5 & 3.80 & 1.04 \\
\hline Organizational Loyalty & 250 & 1 & 5 & 4.02 & .76 \\
\hline I put extra efforts in my job & 250 & 1 & 5 & 4.17 & 1.05 \\
\hline $\begin{array}{l}\text { I use cheaper resources during tours to save } \\
\text { organizational resources }\end{array}$ & 250 & 1 & 5 & 3.37 & 1.19 \\
\hline $\begin{array}{l}\text { If presence of employees is less, I sacrifice my } \\
\text { sanctioned leave }\end{array}$ & 250 & 1 & 5 & 3.77 & 1.04 \\
\hline I promote my organization's products and services & 250 & 1 & 5 & 4.06 & .97 \\
\hline I protect the organizational resources & 250 & 1 & 5 & 4.28 & .76 \\
\hline $\begin{array}{l}\text { I project a good image of my organization to the } \\
\text { people }\end{array}$ & 250 & 1 & 5 & 4.14 & 1.06 \\
\hline I praise the working conditions of my organization & 250 & 1 & 5 & 3.72 & 1.07 \\
\hline Valid N (listwise) & 250 & & & & \\
\hline
\end{tabular}

Source: Field Survey (2018) 
The above results showed that the respondents exhibited altruistic characteristics in their working settings (Mean=3.92, $\mathrm{SD}=.83$ ). The staff of the institution offer their time to help coworkers with-related problems (Mean=3.86, $\mathrm{SD}=1.03$ ). This result is in consonance with the study of Philip, Kumar and Choudhary (2012) that indicated that OCB requires going beyond job requirement in order to help co-workers with work-related challenges. The staff often take time out of their day to aid train new employees as part of the employment and recruitment process of the institution (Mean=3.52, SD=.92) and also help orient new employees even though is not part of their job requirements (Mean=3.54, $\mathrm{SD}=.96$ ). These findings are consistent with previous studies that also indicated that workers sometimes go beyond their required responsibilities to recruit, train and orient new employees (Bukhari et al., 2009; Piliavin, 2009).

Again from the table, it can be seen that the respondents exhibited conscientiousness characteristics in the working environment (Mean=3.74, $\mathrm{SD}=.81$ ). The larger part of the staff rarely take long lunches (Mean=3.62, $\mathrm{SD}=1.27$ ), rarely take extra breaks (Mean=3.62, $\mathrm{SD}=1.16$ ) and also rarely take unnecessary time off work (Mean=3.84, SD=1.14). The attendance of the respondents was above the normal (Mean=3.86, $\mathrm{SD}=1.13$ ). This result is consistent with the study of Bakhshi, Sharma and Kumar (2011) that also emphasized on taking shorter lunch time, shorter breaks, and avoids taking unnecessary time off work as critical elements of the conscientiousness dimension of OCB.

Table 3 further showed that the respondents of the institution exhibited high level of civic virtues (Mean=4.06, SD=.71). The respondents were very punctual in the exhibition of their duties (Mean=4.10, $\mathrm{SD}=.99$ ), and also attended functions that are not required of them but help the company's image and reputation (Mean=3.55, $\mathrm{SD}=1.035$ ). The staff of the institution often volunteer to take additional tasks that are not part of their responsibilities (Mean=3.56, $\mathrm{SD}=1.00$ ), and also attend training programmes they are not required to attend (Mean=3.58, $\mathrm{SD}=1.08$ ). These results are consistent with previous studies that also reported punctuality (McKenna, 2012; Bakhshi, Sharma \& Kumar, 2011), attending non-compulsory meetings but important for the company's image such as keeping up changes in the organization, report suspicious activities (Sharma, Bajpai \& Holani, 2011), taking additional or extra roles or tasks to improve their productivity (Mutharasi, Rajesh \& Karthick, 2014) and the attendance of training programmes they are not required to attend (Rich, Lepine \& Craford, 2010) as critical elements of civic virtues that are also key predictors of employee commitment (Rehan \& Islam, 2013) and hence organizational performance (Rich, Lepine \& Craford, 2010).

Table 3 showed that the staff exhibited high level of sportsmanship in their working environment (Mean=3.88, SD=.72). The exhibited sportsmanship characteristics were in the form of attending and participating in meetings (Mean=3.97, $\mathrm{SD}=.89$ ), reading and keeping up with firm announcements, memos etc. (Mean=3.91, $\mathrm{SD}=.86$ ), making suggestions for practice and policy improvements (Mean=3.70, $\mathrm{SD}=.93$ ), and keeping up with changes in the working environment (Mean=3.86, $\mathrm{SD}=.80$ ). The sportsmanship characteristics exhibited by the staff of the institution were also in the form of keeping trivial complaints to themselves (Mean=3.60, $\mathrm{SD}=1.05$ ), refraining from taking personal credit for teamwork (Mean=3.62, $\mathrm{SD}=1.05$ ), refrained from finding fault with co-workers all the time (Mean=3.58, $\mathrm{SD}=1.10$ ) and largely focused on the positive aspects of their work (Mean=4.15, SD=.94). The sportsmanship characteristics like attending and participating in meetings, reading and keeping up with firm announcements, keeping up with changes in the working environment, refraining from complaining on trivial matters and also taking personal credit for teamwork are all reported to be aimed at maintaining the status quo and promoting social harmony (Becton et al., 2008; Wang et al., 2013). 
Table 3 showed that the staff of the institution exhibited high level of courteous citizenship behaviour in the working environment (Mean=4.04, SD=.69). The exhibited courteous citizenship behaviour of staff of the institution were in the form of been mindful of how their behaviour affects co-workers, avoided any form of problems with co-workers, refrained from abusing the right of co-workers and also refrained from speaking ill of supervisors and coworkers as indicated by the approximate mean of 4.00 . These findings are consistent with previous studies that also reported the act of intimating or warning others before taking actions or making decisions that would affect their work, refraining from abusing the right of coworkers and speaking ill of supervisors and co-workers as critical features of courteous citizenship behaviours (Becton et al., 2008; Gupta \& Singh, 2012).

\subsection{Relationship between OCB, Work Overload and Employee Performance}

Since one of the hypotheses of the study was to test the truism that OCB positively affects employee performance, it was necessary for the researchers to conduct this test by using multiple regression statistical model. This same regression model was also used to test hypotheses 2 and 3 which can be seen in Table 4 below:

Table 4: Mualtiple Regression of the Relationship between OCB, Work Overload and Employee Performance

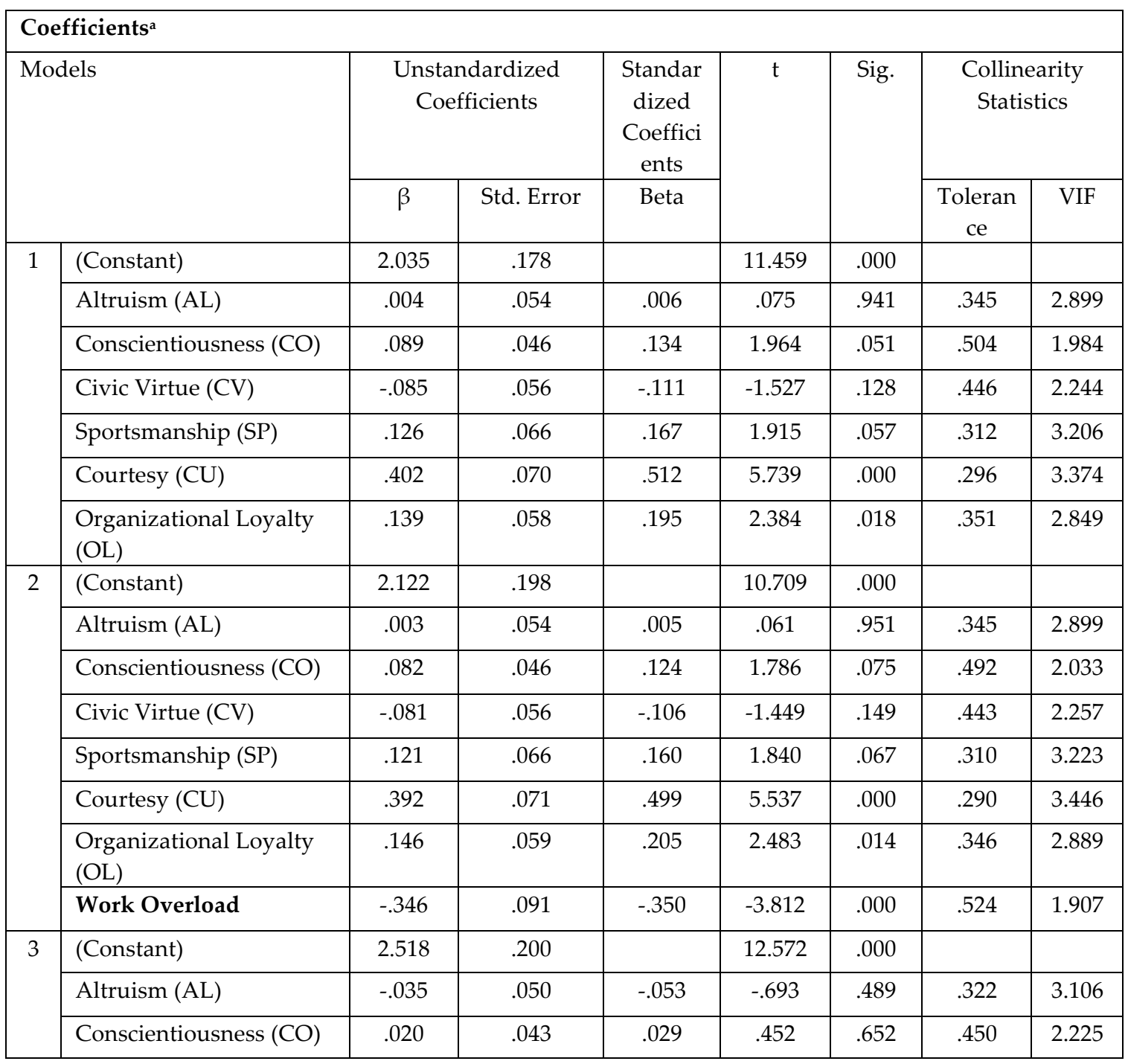




\begin{tabular}{|l|l|c|c|c|c|c|c|c|}
\hline & Civic Virtue (CV) & -.022 & .054 & -.029 & -.417 & .677 & .389 & 2.574 \\
\cline { 2 - 8 } & Sportsmanship (SP) & .116 & .061 & .153 & 1.904 & .058 & .296 & 3.383 \\
\hline Courtesy (CU) & .301 & .069 & .383 & 4.361 & .000 & .247 & 4.041 \\
\hline $\begin{array}{l}\text { Organizational Loyalty } \\
\text { OL) }\end{array}$ & .138 & .055 & .194 & 2.490 & .013 & .316 & 3.166 \\
\hline Work Overload & -.132 & .035 & -.203 & -3.797 & .000 & .668 & 1.498 \\
\hline AL_WL & .366 & .077 & .358 & 4.731 & .000 & .334 & 2.992 \\
\hline CO_WL & .122 & .045 & .151 & 2.736 & .007 & .624 & 1.604 \\
\hline CV_WL & -.087 & .065 & -.073 & -1.348 & .179 & .660 & 1.514 \\
\hline SP_WL & -.285 & .079 & -.229 & -3.603 & .000 & .472 & 2.118 \\
\hline & .103 & .071 & .098 & 1.457 & .147 & .426 & 2.347 \\
\hline CU_WL & .186 & .068 & .178 & 2.715 & .007 & .445 & 2.248 \\
\hline OL_WL & & & & & & \\
\hline
\end{tabular}

Source: Field Survey (2018)

\subsubsection{Effect of $O C B$ on Performance of Employees}

Model 1 of Table 4 shows that there is positive relationship between the conscientiousness behaviours of staff of the institution and their performance $(\beta=.134, p<.10)$. Therefore, a unit increase in conscientiousness attitude of the staff of the institution could stimulate 0.134 unit increase in the performance of employees. This result is in line with the study of Tehran, Abtahi and Esmaeili (2013) that also reported positive relationship between conscientiousness and employee performance of higher educational institutions. The sportsmanship citizenship behaviour of staff of the institution positively influences employee performance $(\beta=.167, p<.10)$. This result therefore implies that 100 percent increase in sportsmanship citizenship behaviour of staff could stimulate approximately 17 percent increase in employee performances. This result is in line with previous studies that also reported positive relationship between sportsmanship and employee performance in the educational sector (Tehran, Abtahi \& Esmaeili, 2013; Noni Huak, Pivi \& Hassan, 2015; Romle, Talib and Shahuri, 2016).

Model 1 of Table 4 further shows that courteous citizenship behaviour of staff of the institution positively influences employee performance $(\beta=.512, \mathrm{p}<.01)$. This result therefore implies that 100 percent increase in courteous citizenship behaviour of staff could stimulate approximately 51 percent increase in employee performances. This result is also in consonance with the study of Romle, Talib and Shahuri (2016) that reported positive relationship between several dimensions of OCB including courtesy and employee performance. Previous studies by Chelagat, Chepkwony and Kemboi (2015) and Basu, Pradhan and Tewari (2017) also reported positive effect of courtesy as a dimension of OCB on employee performance. The loyalty of the staff towards the institution positively influences employee performance $(\beta=.195, \mathrm{p}<.05)$. This result therefore implies that 100 percent increase in loyalty of staff towards the institution could stimulate approximately 20 percent increase in employee performances. This finding is supported by the study of Romle, Talib and Shahuri (2016) that also reported positive relationship between organizational loyalty and employee performance.

Model 2 of Table 4 shows that there is positive relationship between conscientiousness behaviours of staff of the institution and their performance $(\beta=.124, \mathrm{p}<.10)$. Therefore, a 100 percent increase in conscientiousness attitude of staff of the institution could stimulate 12 percent increase in performance of the employees. This result is in line with the study of Tehran, Abtahi and Esmaeili (2013) that also reported positive relationship between 
conscientiousness and employee performance of higher educational institutions. The sportsmanship citizenship behaviour of staff of the institution positively influences employee performance $(\beta=.160, p<.10)$. This result therefore implies that 100 percent increase in sportsmanship citizenship behaviour of staff could stimulate approximately 16 percent increase in employee performances. This result is in line with previous studies that also reported positive relationship between sportsmanship and employee performance in the educational sector (Tehran, Abtahi \& Esmaeili, 2013; Noni Huak, Pivi \& Hassan, 2015; Romle, Talib and Shahuri, 2016).

Model 2 of Table 4 further shows that courteous citizenship behaviour of the staff of the institution positively influences employee performance $(\beta=.499, \mathrm{p}<.01)$. This result therefore implies that 100 percent increase in the courteous citizenship behaviour of the staff could stimulate approximately 50 percent increase in employee performances. This result is also in consonance with the study of Romle, Talib and Shahuri (2016) that reported positive relationship between several dimensions of OCB including courtesy and employee performance. Previous studies by Chelagat, Chepkwony and Kemboi (2015) and Basu, Pradhan and Tewari (2017) also reported positive effect of courtesy as a dimension of OCB on employee performance. The loyalty of the staff towards the institution positively influences employee performance $(\beta=.205, \mathrm{p}<.05)$. This result therefore implies that 100 percent increase in the loyalty of staff towards the institution could stimulate approximately 21 percent increase in employee performances. This finding is supported by the study of Romle, Talib and Shahuri (2016) that also reported positive relationship between organizational loyalty and employee performance.

Model 3 of Table 4 shows that sportsmanship citizenship behaviour of staff of the institution positively influences employee performance $(\beta=.153, p<.10)$. This result therefore implies that 100 percent increase in the sportsmanship citizenship behaviour of staff could stimulate approximately 15 percent increase in employee performances. This result is in line with previous studies that also reported positive relationship between sportsmanship and employee performance in the educational sector (Tehran, Abtahi \& Esmaeili, 2013; Noni Huak, Pivi \& Hassan, 2015; Romle, Talib and Shahuri, 2016). Model 3 of Table 4 further shows that courteous citizenship behaviour of the staff of the institution positively influences employee performance $(\beta=.383, p<.01)$. This result therefore implies that 100 percent increase in courteous citizenship behaviour of staff could stimulate approximately 38 percent increase in employee performances. Previous studies by Chelagat, Chepkwony and Kemboi (2015) and Basu, Pradhan and Tewari (2017) also reported positive effect of courtesy as a dimension of OCB on employee performance. The loyalty of staff towards the institution positively influences employee performance $(\beta=.194, \mathrm{p}<.05)$. This result therefore implies that 100 percent increase in the loyalty of the staff towards the institution could stimulate approximately 19 percent increase in employee performance. This finding is supported by the study of Romle, Talib and Shahuri (2016) that also reported positive relationship between organizational loyalty and employee performance. Based on models 1, 2 and 3 of Table 4, we accept the hypothesis that OCB positively affects employee performance.

\subsubsection{Effect of work overload on performance of employees}

Model 2 of Table 4 shows that work overload of the staff of the institution negatively affects employee performance $(\beta=-.350, p>.01)$. This result implies that 100 percent increase in work overload of the workers is related to about 35 percent decrease in the performance of the employee of the institution. Model 3 of Table 4 also showed that work overload of the staff of the institution negatively or adversely affects the performance of the employees $(\beta=-.203$, $\mathrm{p}<.01)$. This result therefore implies that 100 percent increase in the work overload of staff of the institution could stimulate approximately 20 percent decrease in the performance of the 
employees. The result of the estimated models are consistent with previous studies that also reported adverse or negative effect of work overload on employee performance as can be found in Tahir, Yusoff, Azam, Khan, \& Kaleem, (2012); Paktinat \& Rafeei, (2012); Ashfaq, Mahmood \& Ahmad, (2013); Karatepe, (2013). These researchers further emphasized that work overload is harmful not to just the employees but to the entire organization (Obiora \& Iwuoha, 2013). Based on models 2 and 3, we therefore accepts our hypothesis that work overload negatively affects employee performance.

\subsubsection{Moderating Effect of Work Overload on the Effect of OCB on Performance of Employees}

Model 3 of Table 4 shows that work overload interacted with altruism (predictor) $(\beta=.358$, $\mathrm{p}<.01)$ and was also related to performance (criterion variable) $(\beta=-.202, \mathrm{p}<.01)$. This therefore indicates that work overload was a Quasi-Moderator in the relationship between altruism and employee performance. Work overload also interacted with conscientiousness (predictor) $(\beta=.151, \mathrm{p}<.01)$ and was also related to performance (criterion variable) $(\beta=-.202, \mathrm{p}<.01)$. This therefore indicates that work overload was a Quasi-Moderator in the relationship between conscientiousness and employee performance. Nonetheless, work overload failed to interact with civic virtue but was related to performance (criterion variable) $(\beta=-.202, p<.01)$. This therefore indicates that work overload was just an intervening variable or exogenous variable in the relationship between civic virtue and employee performance.

Model 3 of Table 4 further shows that work overload interacted with sportsmanship (predictor) $(\beta=-.229, \mathrm{p}<.01)$ and was also related to performance (criterion variable) $(\beta=-.202, \mathrm{p}<.01)$. This therefore indicates that work overload was a Quasi-Moderator in the relationship between sportsmanship citizenship behaviour and employee performance. Work overload also interacted with organizational loyalty (predictor) $(\beta=.178, \mathrm{p}<.01)$ and was also related to performance (criterion variable) $(\beta=-.202, \mathrm{p}<.01)$. This therefore indicates that work overload was a Quasi-Moderator in the relationship between organizational loyalty and employee performance. However, work overload failed to interact with courtesy but was related to performance (criterion variable) $(\beta=-.202, \mathrm{p}<.01)$. This therefore indicates that work overload was just an intervening variable or exogenous variable in the relationship between courteous behaviour and employee performance. Kaplan, Bradley, Luchman and Haynes (2009) in support of negative moderation indicated that employees who experience stress due to high workload tend to engage less in $\mathrm{OCB}$ as is otherwise perceived to adversely affect their performance due to their low coping ability. Largely there was significant evidence based on model 3 of table 4 that work overload moderates the effect of OCB on employee performance and therefore makes us to accept our third hypothesis though this was not supported in the area of OCB of civic virtue and courtesy.

\section{Conclusion}

It is not possible to have all the job description and specification fully spelt out in the appointment letter that engaged the employee as some of them are implied. It is therefore important that employees exhibit certain OCB that will play a significant role in assisting and motivating others to perform extremely well. The study confirmed based on the selected dimensions of OCB that educational institutions should encourage and promote OCB at the workplace since they impact positively on employees' performance. On other hand, work overload should be discourage as it is a negative predictor of employees performance. Work overload normally generates stress and fatigue which could easily burnt out the employee and hence produce negative performance.

Therefore OCB will be more beneficial to the employee and the organization when it is exhibited during the contractual hours established between the employee and the employer. It 
is based on this that the National Council for Tertiary Education (NCTE) which is a regulator of tertiary institutions in Ghana has set up a standard with regard to student/lecturer ratio in order to ensure that lecturers do not over work themselves since work overload has the tendency of affecting the quality of service rendered to students.

\section{Limitation and recommendation for further research}

The study geographically focused on Kumasi Technical University and hence reduces the validity in terms of generalizing the findings to all higher educational institutions in Ghana. This study therefore suggested that future studies in this academic field expand the scope to include several higher educational institutions selected countrywide. Again it focused largely on identifying the moderators of the effects of $O C B$ on employee performance with no attention to possible mediators. Future studies on $\mathrm{OCB}$ could investigate the mediators in the relationship between $\mathrm{OCB}$ and employee performance.

\section{References}

Abbasi, T. F. (2015). Impact of Work Overload on Stress, Job Satisfaction, and Turnover Intentions with Moderating Role of Islamic Work Ethics. Management Studies and Economic Systems (MSES), 2(1), 27-37.

Agustiningsih, H. N., Thoyib, A., Djumilah, H. \& Noermijati, N. (2016). The Effect of Remuneration, Job Satisfaction and OCB on the Employee Performance. Science Journal of Business and Management, 4(6), 212-222.

Ali, S. \& Farooqi, Y. A. (2014). Effect of Work Overload on Job Satisfaction, Effect of Job Satisfaction on Employee Performance and Employee Engagement (A Case of Public Sector University of Gujranwala Division). International Journal of Multidisciplinary Sciences and Engineering, 5(8), 23-30.

Ashfaq, S., Mahmood, Z. \& Ahmad, M. (2013). Impact of Work-Life Conflict and Work over Load on Employee Performance in Banking Sector of Pakistan. Middle-East Journal of Scientific Research, 14(5), 688-695.

Awang, Z., Ahmad, J. H. \& Zin, N. M. (2010). Modelling Job Satisfaction and Work Commitment among Lecturers: A Case of UiTM Kelantan. Journal of Statistical Modeling and Analytics, 1(2), 45-59.

Bakhshi, A., Sharma, A. D. \& Kumar, D. (2011). Organizational Commitment as predictor of Organizational Citizenship Behavior.European Journal of Business and Management, 3(4), 234-256.

Basu, E., Pradhan, R. K. \& Tewari, H. R. (2017). Impact of organizational citizenship behavior on job performance in Indian healthcare industries: The mediating role of social capital. International Journal of Productivity and Performance Management, 66(6), 780-796.

Becton, J. B., Giles, W. F., \& Schraeder, M. (2008). Evaluating and rewarding OCB's; potential consequences of formally incorporating organizational citizenship behavior in performance appraisal and reward system. Employee relations, 30(5), 494-514.

Boyd, R., Henrich, J., Bowles, S., Camerer, C., Fehr, E., Gintis, H., \& McElreath, R. (2011). In search of homo economics: Behavioral experiments in 15 small-scale societies. The American Economic Review, 91, 73-78, 
Bozkurt, V., Aytac, S., Bondy, J., \& Emirgil, B. F. (2012). Job Satisfaction, Role overload and Gender in Turkey. 51-67.

Bukhari, Z., Aki, U., Shahzad, K., \& Bashir, S. (2009). Determinants of Organizational Citizenship Behavior in Pakistan. International Review of Business Research Papers, 5(2), 345-364.

Chelagat, L. J., Chepkwony, P. K. \& Kemboi, A. (2015). Effect of Organizational Citizenship Behavior on Employee Performance in Banking Sector, Nairobi County, Kenya. International Journal of Business, Humanities and Technology, 5(4), 55-61.

Farahbod, F., Azadehdel, M., Rezaei, M. \& Nezhadi, M., (2012), Organizational citizenship behavior: The role of organizational justice and leader-member exchange. Interdisciplinary journal of contemporary research in business. 3 (9), 893-903.

Goldberg, L.R. (1999). A broad-bandwidth, public domain, personality inventory measuring the lower-level facets of several five-factor models. In Mervielde, I., Deary, I., De Fruyt F. \&Ostendorf, F.(Eds.), Personality psychology in Europe, Vol. 7 (pp. 7-28). Tilburg, the Netherlands: Tilburg University Press. 78

Gupta, V., \& Singh, S. (2012). Empirical Evaluation of Dimensionality of Organizational Citizenship Behavior from Indian Business Context. National Academy of Psychology, 57 (4), 392-407.

Hakim, W., Nimran, U., Haerani, S. \& Alam, S. (2014). The Antecedents of Organizational Citizenship Behavior (OCB) and Their Effect on Performance: Study on Public University in Makassar, South Sulawesi, Indonesia. IOSR Journal of Business and Management (IOSR-JBM), 16(2), 05-13.

Kaplan, S., Bradley, J. C., Luchman, J. N., \& Haynes, D. (2009). On the role of positive and negative affectivity in job performance: a meta-analytic investigation. Journal of Applied Psychology, 94(1), 162-176.

Karatepe, O. M. (2013). The effects of work overload and work-family conflict on job embeddedness and job performance: The mediation of emotional exhaustion. International Journal of Contemporary Hospitality Management, 25(4), 614-634,

Khazaei, K., Khalkhali, A. \& Eslami, N. (2011). Relationship between Organizational Citizenship Behavior and Performance of School Teachers in West of Mazandaran Province. World Applied Sciences Journal, 13(2), 324-330.

Kılınç, E. \& Ulusoy, H. (2014). Investigation of organizational citizenship behavior, organizational silence and employee performance at physicians and nurses, and the relationship among them. Business Management Dynamics, 3(11), 25-34.

Mate, S. G. (2014). Sources of Stress and Coping Strategies Adopted By Academic Senior Members in the University of Cape Coast. International Journal of Research in Social Sciences, 4(2), 31-39

McGinnity, F. \& Whelan, C.T. (2009). Comparing Dual-Income Lifestyle. Journal of Marriage and Work-Life Conflict in Europe: Evidence from the European Social Survey. Soc Indic Res., 93, 433-444.

McKenna, E. (2012). Business Psychology and Organizational Behaviour 5th ed. New York: Psychology press. 
Mutharasi,P., Rajesh,S,S and Karthick,B,M(2014).Can entry-level employees become good soldiers? A study on their Organizational Citizenship Behavior.The International's Research Journal of Economics and Business Studies, 3(3), 34-56.

Nielsen, T. M., Hrivnak, G. A., \& Shaw, M. (2009). Organizational citizenship behavior and performance: A meta-analysis of group-level research. Small Group Research, 40(5), 555577.

Noni Huak, M. D., Pivi, F. G. \& Hassan, Z. (2015). The Impact of Organizational Citizenship Behaviour on Employee's job satisfaction, commitment and turnover intention in Dining Restaurants Malaysia. International Journal of Accounting, Business and Management, 1(1), $1-17$.

Obiora, C. A., \& Iwuoha, V. C. (2013). Work Related Stress, Job Satisfaction and Due Process in Nigerian Public Service. European Scientific Journal, 9(20), 214-232.

Paktinat, D., \& Rafeei, I. (2012). Studying the effect of stress factors of on the amount of customers dissatisfaction with using Structural Equation Model (A Case from insurance companies in Kerman). Interdisciplinary Journal of Contemporary Research in Business, 3(12), 108-116.

Philip, P. J., Kumar, R. \& Choudhary, N. (2012). Relationship between Organizational Citizenship Behavior and Organizational Justice at Work Place. Ninth AIMS International Management, 2(8), 34-45.

Piliavin, J. A. (2009).Altruism and Helping: The Evolution of a Field: The 2008 Cooley-Mead Presentation.Social Psychology Quarterly, 72(209), 234-256.

Podsakoff, N.P., Whiting, S.W., Podsakoff, P.M. and Mishra, P. (2011). Effects of organizational citizenship behaviors on selection decisions in employment interviews. Journal of Applied Psychology, 96, 310-326.

Rehan, M. \& Islam, T. (2013).Relationship Between Organizational Commitment and Citizenship Behaviours.World Journal of Management and Behavioral Studies, 1(1), 24-32.

Reich, R.B. (2001). The Future of Success. Knopf Doubleday Publishing Group.

Rich, B. L., Lepine, J. A., \& Craford, E. R. (2010). Job Engagement: Antecendts and effects on job performance .Academy of Management Journal, 53(3), 617-635.

Romle, A. R., Mohd Talib, N. F. \& Sofian Shahuri, N. S. (2016). The relationship between organizational citizenship behavior and high performance organization from the perspective of the students in the higher education institution in Malaysia. Journal of Scientific Research and Development, 3(5), 37-42,

Rose, K. J. (2012). Organizational Citizenship Behaviors in Higher Education: Examining the Relationships between Behaviors and Performance Outcomes for Individuals and Institutions. Theses and Dissertations. 403.

Saleem, A., Nisar, Q. A. \& Imran, A. (2017). Organization citizenship behaviour, psychological empowerment and demographic characteristics: Teachers' perspective. International Journal of Advanced and Applied Sciences, 4(7), 129-135.

Saranani, F. (2015). Role conflict and stress effect on the performance of employees working in public works department. The International Journal of Engineering and Science (IJES), 4 (6), $1-10$. 
Sharma,P., Bajpai,N., and Holani,U.,(2011).Organizational Citizenship Behavior in Public and Private Sector and Its Impact on Job Satisfaction: A Comparative Study in Indian Perspective.International Journal of Business and Management, 6(1), 23-40.

Tahir, S., Yusoff, R. b., Azam, K., Khan, A., \& Kaleem, S. (2012). The Effects of Work Overload on the Employees' Performance in relation to Customer Satisfaction: A Case of Water \& Power Development Authority, Attock, Pakistan. World Journal of Social Sciences, 2(1), 174-181.

Tehran, G. M., Abtahi, M. S. \& Esmaeili, S. (2013). The Relationship between Organizational Citizenship Behavior and Performance of the Staff of Qazvin University of Medical Sciences and Health Services. International Journal of Academic Research in Business and Social Sciences, 3(9), 534-542

Wang, L., Hinrichs, K. T., Prieto, L., \& Howell, J. P. (2013). Five Dimensions of Organizational Citizenship Behavior: Comparing Antecedents and Levels of Engagement in China and the USA. Asia Pacific Journal of Management, 30, 115-147.

Yahya, A., Boon, Y., Ramli, J., Baharudin, N., Yahaya, N., Ismail, J \& Shariff, J., (2011). The implications of Organizational Citizenship Behavior (OCB) towards the dimensions of Learning Organization (LO) in organizations in Southern Malaysia. African Journal of Business Management, 5(14), 5724-5737. 